\title{
Filogenetik Ular Sanca Batik (Malayopython reticulatus) Lokal Jawa Berdasar Sekuen Gen Sitokrom B
}

\author{
(PHYLOGENETIC STUDY OF RETICULATED PYTHON (MALAYOPYTHON \\ RETICULATUS) JAVAN LOCALITY BASED ON GENE CYTOCHROME B SEQUENCES)
}

\author{
Slamet Raharjo ${ }^{1 *}$, Sri Hartati ${ }^{1}$, Soedarmanto Indarjulianto ${ }^{1}$, \\ Rini Widayanti ${ }^{2}$ Alfarisa Nururrozi ${ }^{1}$ \\ ${ }^{1}$ Departemen Ilmu Penyakit Dalam. ${ }^{2}$ Departemen Biokimia \\ Fakultas Kedokteran Hewan, Universitas Gadjah Mada \\ Jl. Fauna No 2, Kampus UGM, Karangmalang, Yogyakarta \\ Tel : +62-274-560862, Fax +62-274-560861 \\ Email: raharjo_vet19@yahoo.com
}

\begin{abstract}
ABSTRAK
Ular sanca batik jawa (Malayopython reticulatus) memiliki fenotip yang berbeda antara ular sanca batik asal Jawa Barat, Jawa Tengah dan Jawa Timur. Penelitian ini bertujuan untuk mengetahui filogenetik ular sanca batik (M. reticulatus) lokal Jawa berdasar sekuen gen sitokrom b parsial. Sebanyak 15 ekor ular sanca batik dewasa sehat, jenis kelamin jantan dan betina (5 dari Jawa Barat, 5 dari Jawa Tengah dan 5 dari Jawa Timur) digunakan dalam penelitian ini. Sampel darah sebanyak $1 \mathrm{~mL}$ dikoleksi dari tiap ular dan ditampung dalam tabung eppendorf ber-EDTA. Analisis dilakukan di Laboratorium Biokimia FKH UGM meliputi ekstraksi DNA total, amplifikasi DNA dengan teknik PCR. Sekuensing DNA dilakukan di First Base Company Singapore oleh PT. Genetika Science Jakarta. Data hasil sekuensing gen sitokrom b dianalisis untuk penentuan filogenetik menggunakan metode Neighbor joining (MEGA v. 5.0). Panjang sekuen nukleotida gen sitokrom b parsial, M.reticulatus lokal Jawa Barat, Jawa Tengah dan Jawa Timur adalah sekitar 819 bp. Hasil filogram menggunakan metode Neighbor joining menunjukkan M. reticulatus lokal Jawa Tengah dapat dibedakan dari Jawa Barat, sedangkan lokalitas Jawa Timur tidak dapat dibedakan dari Jawa Barat dan Jawa Tengah, yaitu dalam kelompok yang sama. Dapat disimpulkan bahwa $M$. reticulatus lokal Jawa memiliki keseragaman panjang nukleotida gen sitokrom b parsial yaitu 819 bp. Filogenetik M. reticulatus lokal Jawa Barat dan beberapa lokal Jawa Timur berada dalam cabang yang sama dengan $M$. reticulatus GenBank, sedangkan $M$. reticulatus asal Jawa Tengah dan beberapa dari Jawa Timur berada dalam cabang berbeda. Perlu penelitian lebih lanjut dengan jumlah sampel yang lebih banyak dan validitas lokalitas sehingga hasil lebih akurat.
\end{abstract}

Kata-kata kunci: filogenetik; Malayopython reticulatus; lokalitas Jawa; sitokrom b

\begin{abstract}
Reticulated python (Malayopython reticulatus) Javan locality has different phenotype among West Java, Central Java and East Java locality. This research aim was to study the phylogenetic of reticulated python ( $M$. reticulatus) Java locality based on the partial gene cytochrome b sequences. Fifteen males and females adult healthy reticulated pythons (5 from West Java, 5 from Central Java and 5 from East Java) were used in this study. As much as $1 \mathrm{~mL}$ blood samples collected from ventral coccygeal vein, put in Eppendorf with EDTA then sent to Laboratory of Biochemistry, Faculty of Veterinary Medicine, Gadjah Mada University for total Deoxyrybo Nucleic Acid (DNA) extraction and DNA amplification with Polymerase Chain Reaction (PCR) method. DNA sequencing was done in First Base Company Singapore by PT. Genetika Science Jakarta. The gene cytochrome b sequences were phylogenetically analysed using Neighbor joining (MEGA v. 5.0) method. The length of partial gene cytochrome b nucleotides sequence of M. reticulatus from West Java, Central Java and East Java locality was 819 bp. The phylogram using Neighbor joining method showed that Malayopython reticulatus Central Java locality was differentiated from West Java locality, while the East Java locality was undifferentiated from West Java and Central Java locality, namely in the same group. It could be concluded that reticulated python (M. reticulatus) Java locality has
\end{abstract}


partial gene cytochrome b sequences with $819 \mathrm{bp}$. The phylogenetic of Malayopython reticulatus West Java and several from East Java were located at same branch with $M$. reticulatus GenBank, while the Central Java and several from East Java were located at different branch. It needs further research with more samples and validity of localities for better result.

Key words: phylogenetic; Malayopython reticulatus; Java locality; cytochrome b

\section{PENDAHULUAN}

Indonesia merupakan habitat alami bagi banyak spesies ular termasuk ular sanca batik (Malayopython reticulatus) (Reynold et al., 2014; Low et al., 2016). Ular sanca batik memiliki tubuh yang besar, berotot dengan kulit bermotif seperti jaring dan bagian punggung memiliki pola seperti berlian ireguler. Spesies ular ini ditemukan dalam berbagai variasi ukuran tubuh, warna, pola, motif dan saat ini, meski bukan yang terberat, namun diakui sebagai ular dan reptil terpanjang di dunia (Auliya, 2002).

Distribusi $M$. reticulatus di Indonesia menyebar dari Pulau Anambas, Banda Besar, Bangka, Belitung, , Buru, Butung, Enggano, Flores, Halmahera, Haruku, Jawa, Kalimantan, Krakatau, Lombok, Kepulauan Mentawai, Natuna, Nias, Obira, Riau, Saparua, Seram, Simeulue, Sula, Sulawesi, Sumatra, Sumba, Sumbawa, Tanimbar, Ternate, Timor dan Verlate (Auliya et al., 2003; Wanger et al., 2011). Distribusi $M$. reticulatus di luar Indonesia meliputi Bangladesh, Brunei Darussalam, Kamboja, India, Laos, Malaysia, Myanmar, Filipina, Singapura, Thailand dan Vietnam.

Ada beberapa perubahan nama ilmiah membingungkan yang terjadi dalam beberapa tahun terakhir untuk spesies $M$. reticulatus (Kaiser et al., 2013). Spesies ini pertama kali diberi nama ilmiah Boa reticulata dan diubah menjadi Python reticulatus oleh Schneider pada tahun 1801. Sampai tahun 2000an, nama ilmiah yang digunakan adalah Python reticulatus. Reklasifikasi membuat nama genus menjadi Broghammerus, sehingga nama spesies berubah menjadi Broghammerus reticulatus (Rawlings, et al., 2008). Perubahan nama terjadi tahun 2011, dengan mengembalikan nama Broghammerus reticulatus ke Python reticulatus (Relox et al., 2011) dan perubahan nama terakhir menjadi $M$. reticulatus pada tahun 2014 diterima secara luas (Reynolds et al., 2014; Barker et al., 2015). Saat ini M. reticulatus terklasifikasi dibawah Kingdom Animalia, Filum Chordata, subfilum Vertebrata, kelas Reptilia, ordo Squamata, famili Pythonidae, genus Malayopython dan species Malayopython reticulatus bersama dengan $M$. timorensis.

Ular sanca batik di Indonesia khususnya Jawa dan Sumatra umum dipelihara. Fakta di lapangan ditemukan adanya variasi ukuran tubuh, warna, motif, karakter, tingkah laku dan reproduksi. Ular sanca batik Jawa, diketahui memiliki beberapa variasi fenotip terutama pada warna tubuh misalnya perbedaan warna kepala, perut dan badan pada ular sanca batik asal Jawa Barat, Jawa Tengah dan Jawa Timur (Raharjo, 2008). Namun, sampai saat ini belum diketahui bagaimana filogenetiknya.

Mitokondria merupakan organela di luar inti sel yang mengandung sekitar 16,5 x 103/3,3 x $10^{9}$ dari DNA (DNA Mitokondria/mt DNA) yang ditemukan di dalam sel manusia. Kemungkinan untuk memperoleh kembali mt-DNA dari sampel biologis dalam jumlah kecil atau dari sampel biologis yang sudah terdegradasi adalah lebih besar daripada DNA inti karena molekul mt-DNA terdapat dalam ratusan sampai ribuan kopi dibanding dengan DNA inti yang hanya dua kopi pada setiap sel.

Sekuen DNA mitokondria dipilih sebagai penanda genetik karena ukurannya relatif kecil (sekitar 16,5 kb), terdapat dalam jumlah kopi yang banyak sehingga mudah didapat dari sel dan diturunkan dari induk betina. Menurut Reyes et al. (1998), mutasi pada genom mitokondria disebabkan kurangnya sistem reparasi DNA dan adanya kerusakan oksidatif akibat radikal bebas yang dihasilkan selama transpor elektron ke oksigen yang mengambil tempat pada tingkat rantai respirasi komplek di membran dalam mitokondria. Genom mitokondria memiliki kecepatan evolusi 5-10 x lebih cepat daripada genom inti.

Fragmen penyandi protein di dalam genom mitokondria yaitu sitokrom b, sitokrom oksidasec dan gen lainnya (Randi, 1996). Sitokrom b memiliki banyak variasi urutan, menjadikan gen ini banyak digunakan untuk membandingkan spesies dalam genus yang sama atau famili yang sama, seperti yang dilakukan oleh Ozawa et al. (1997) pada mammoth dan Steller's sea cow; Randi dan Lucchini, (1998) pada genus Alectoris dan Widayanti et al. (2006) pada Tarsius sp. Menurut Butorina et al. (2000) 
urutan gen sit b (ukuran $1020 \mathrm{pb}$ ) dari empat genus burung famili Tetraonidae yang diteliti terdapat 186 nukleotida bersifat variatif dan tersebar merata dalam gen. Substitusi sebagian besar sinonimus, penggantian asam amino hanya terdeteksi 15 dari 340 asam amino. Transisi antar C-T paling sering terjadi $(60,7 \%)$ dan tranversi G-C paling jarang terjadi (5,9\%). Frekuensi mutasi tinggi pada posisi kodon ke-3 (85,2\%). Kejadian tersebut $80 \%$ terjadi pada spesies Alectoris (A. barbara, A. melanocephala, A. rufa, A. graeca, A. chukar, A. magna, dan A. philbyi). Pada kodon ke-3 kandungan $\mathrm{G}$ paling rendah $(3,3 \%)$ dan $\mathrm{C}$ paling tinggi $(44,5 \%)$. Namun demikian penelitian keragaman daerah penyandi protein sitokrom b untuk melihat hubungan antar spesies pada $M$. reticulatus lokalitas Jawa belum dilaporkan.

Penelitian ini bertujuan untuk mengetahui filogenetik ular sanca batik Jawa berdasarkan sekuen gen sitokrom b. Hasil penelitian ini diharapkan dapat digunakan sebagai referensi dalam penentuan spesies ular sanca batik ( $M$. reticulatus) Jawa.

\section{METODE PENELITIAN}

Dalam penelitian ini adalah 15 ekor ular sanca batik jawa dewasa sehat dengan jenis kelamin jantan dan betina serta diketahui dengan jelas asal-usul lokalitasnya. Sampel diperoleh dari pemburu ular di Jawa Barat, Jawa Tengah dan Jawa Timur.

Material DNA yang digunakan adalah ekstraksi dari sampel darah ular sanca batik lokal Jawa Barat (5 sampel), Jawa Tengah (5 sampel) dan Jawa timur (5 sampel). Sampel darah sebanyak $1 \mathrm{~mL}$ dikoleksi dari tiap ular dan ditampung dalam tabung ber-EDTA. Analisis dilakukan di Laboratorium Biokimia FKH UGM meliputi ekstraksi DNA total, amplifikasi DNA dengan teknik PCR. Sekuensing DNA dilakukan di First Base Company Singapore oleh PT. Genetika Science
Jakarta. Data hasil sekuensing gen sitokrom b dianalisis untuk penentuan filogenetik menggunakan metode Neighbor joining (MEGA v. 5.0).

\section{Ekstraksi DNA}

Material DNA yang digunakan berasal dari sampel darah ular sanca batik lokal Jawa Barat (5 sampel), Jawa Tengah (5 sampel) dan Jawa Timur (5 sampel). Sampel darah dipreservasi menggunakan 10\% EDTA sebagai antikoagulan agar darah tidak menggumpal. Ekstraksi DNA dari sampel darah mengikuti metode Sambrook et al. (1989). Darah sebanyak 250 iL ditambah $1 \mathrm{x}$ volume larutan lisis $\{0,32 \mathrm{M}$ Sucrose, $1 \%(\mathrm{~V} /$ V) Triton X-100, $5 \mathrm{mM} \mathrm{MgCl} \mathrm{Man}_{2}$ do mM Tris$\mathrm{HCl}, \mathrm{pH} 7,4\}$. Organel sel dalam larutan diendapkan dengan sentrifugasi $6500 \mathrm{rpm}$ selama 1 menit. Endapan ditambah dengan $1 \mathrm{x}$ volume larutan pencuci $(75 \mathrm{mM} \mathrm{NaCl}, 50 \mathrm{mM}$ EDTA, pH 8,0). Langkah selanjutnya diinkubasi pada penangas air suhu $55^{\circ} \mathrm{C}$ selama \pm 16 jam atau semalam.

Pemurnian DNA total mengikuti metode Sambrook et al. (1989). Suspensi setelah diambil dari penangas air ditambah fenol $1 \mathrm{x}$ volume, dicampur rata kemudian disentrifugasi 13.000 rpm selama 3 menit. Fase atas yang mengandung DNA dipindah ke tabung baru, kemudian ditambah kloroform:isoamil-alkohol (24:1, CIAA) dan dicampur rata. Fase atas dipisahkan dengan sentrifugasi $13.000 \mathrm{rpm}$ selama 3 menit. Cairan bagian atas dipindahkan ke tabung baru, ditambah etanol absolut $2 \mathrm{x}$ volume. Gumpalan DNA diendapkan dengan sentrifugasi $13.000 \mathrm{rpm}$ selama 5 menit. Endapan DNA dicuci menggunakan alkohol 70\% 1x volume dengan sentrifugasi $13.000 \mathrm{rpm}$ selama 3 menit. Endapan DNA yang diperoleh dikeringkan pada suhu ruang. Edapan DNA dilarutkan dalam larutan TE (10 mM Tris-HCl; 1 mM EDTA, pH 8,0), kemudian diinkubasi pada penangas air suhu $37^{\circ} \mathrm{C}$ selama 15 menit. Sampel DNA disimpan pada suhu $-20^{\circ} \mathrm{C}$. DNA dilihat kualitasnya dengan dimigrasikan pada gel

Tabel 1. Urutan basa dan suhu penempelan primer untuk mengamplifikasi gen sit b Malayopython reticulatus.

\begin{tabular}{lcccc}
\hline Target & R/F & Primer & & \\
& Urutan Basa & Easa & Suhu Penempelan \\
\hline Sit B & F & 5' tgccccaccactatatcctaac 3' & 22 & $55^{\circ} \mathrm{C}$ \\
Sit B & R & 5' gtaggatgccataggcgaatag 3' & 22 & $55^{\circ} \mathrm{C}$ \\
\hline
\end{tabular}


agarosa 1,2\% dengan menggunakan buffer 1xTBE (89 mM Tris, $89 \mathrm{mM}$ asam borat dan 2 mM EDTA, $\mathrm{pH}$ 8,0) dalam piranti Submarine Electrophoresis (Hoefer, USA). Pengamatan dilakukan dengan bantuan sinar UV setelah gel diwarnai dengan DNA staining Goodview (Invitrogen).

\section{Amplifikasi DNA (PCR)}

DNA total hasil ekstraksi dipergunakan sebagai DNA cetakan untuk proses amplifikasi. Primer-primer yang dipergunakan dalam penelitian ini didisain untuk mengamplifikasi gen sit b parsial (Tabel 1). Primer untuk sit b disusun berdasarkan data urutan Python regius (Kode akses Gene bank NC_007399).

Komposisi $50 \mu \mathrm{L}$ campuran pereaksi PCR terdiri dari 2,5 $\mathrm{mM} \mathrm{MgCl}, 10 \mathrm{mM}$ dNTPs, 100 300 ng DNA cetakan, 10 pmol masing-maing primer dan 2 U Taq polimerase (Bio Lab) beserta bufernya. Amplifikasi PCR pada penelitian ini menggunakan mesin PCR (Infinigen). Amplifikasi gen sit b parsial dilakukan dengan kondisi sebagai berikut: denaturasi awal selama 5 menit pada suhu $94^{\circ} \mathrm{C}$ selanjutnya diikuti dengan $94^{\circ} \mathrm{C}$ selama 30 detik, $55^{\circ} \mathrm{C}$ selama 45 detik, $72^{\circ} \mathrm{C}$ selama 1 menit sebanyak 35 siklus kemudian diakhiri 5 menit pada $72^{\circ} \mathrm{C}$.

Produk PCR dideteksi dengan cara dimigrasikan pada gel agarose 1,2\% dengan menggunakan buffer 1xTBE dalam piranti Submarine Electrophoresis (Hoefer, USA). Hasil PCR diketahui dengan bantuan sinar UV setelah gel diwarnai dengan DNA stain Goodview (Invitrogen). Untuk mengetahui ukuran DNA hasil amplifikasi menggunakan marker DNA $100 \mathrm{bp}$.
Untuk keperluan sekuensing, hasil PCR dipurifikasi menggunakan GFX Column purification kit (Amersham, USA), selanjutnya dipergunakan sebagai DNA cetakan untuk reaksi pengurutan nukleotida. Urutan nukleotida gen sit b diperoleh dengan menggunakan alat pengurut DNA otomatis ABI Prism versi 3.4.1 (USA). Kondisi untuk reaksi sekuensing adalah: denaturasi awal selama 5 menit pada suhu $94^{\circ} \mathrm{C}$ diikuti dengan $94^{\circ} \mathrm{C}$ selama 30 detik, $55^{\circ} \mathrm{C}$ selama 45 detik, $72^{\circ} \mathrm{C}$ selama 1 menit sebanyak 35 siklus dan diakhiri dengan extension selama 5 menit pada $72^{\circ} \mathrm{C}$. Data hasil sekuensing gen sitokrom b dianalisis untuk penentuan filogenetik dengan metode Neighbor joining (MEGA v. 5.0).

\section{HASIL DAN PEMBAHASAN}

Hasil amplifikasi gen sitokrom b sampel $M$. reticulatus lokal Jawa Barat, Jawa Tengah dan Jawa Timur menunjukkan panjang band yang sama yaitu sekitar 819 bp (Gambar 1).

Panjang band yang sama mengindikasikan kesamaan genetik $M$. reticulatus Jawa. Hasil ini sesuai dengan pendapat Butorina et al. (2000) dan Widayanti et al. (2006) bahwa spesies yang sama memiliki panjang band yang sama.

Jarak genetik $M$. reticulatus lokalitas Jawa berdasar perbedaan nukleotida (819 nt) sitokrom b menggunakan metode Kimura 2 parameter menunjukkan adanya jarak genetik yang kecil yaitu 1,1-1,7\% (Tabel 2). Jarak genetik yang kecil menunjukkan keseragaman genetik yang tinggi atau keragaman genetik yang rendah.

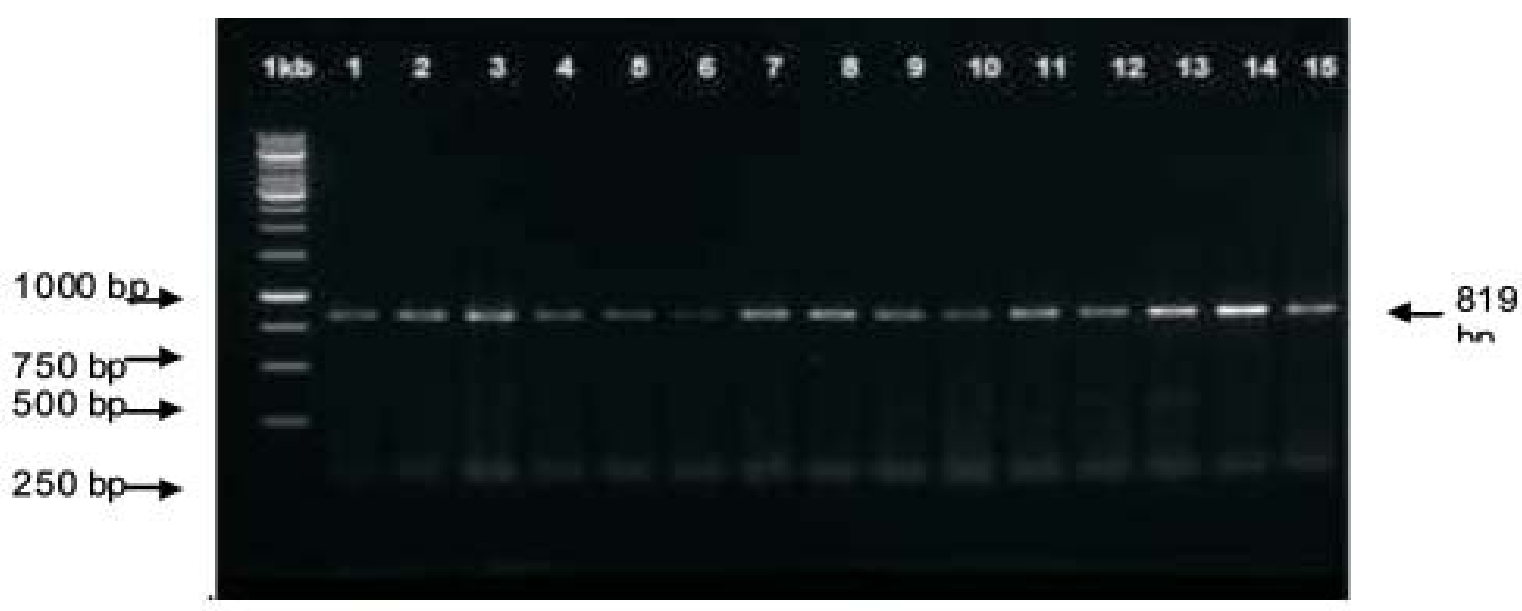

Gambar 1. Hasil amplifikasi gen sitokrom b sampel Malayopython reticulatus lokal Jawa Barat, Jawa Tengah, dan Jawa Timur pada gel agarose 1\%. 
Tabel 2. Tabel jarak genetik Malayopython reticulatus sampel penelitian berdasar sekuen nukleotida (819 nt) menggunakan metode Kimura 2 parameter

\begin{tabular}{|c|c|c|c|c|c|c|c|c|c|c|c|c|c|c|c|c|c|}
\hline & Nama & 1 & 2 & 3 & 4 & 5 & 6 & 7 & 8 & 9 & 10 & 11 & 12 & 13 & 14 & 15 & 16 \\
\hline 1 & Sampel Jatim 1 & 0.011 & & & & & & & & & & & & & & & \\
\hline 2 & Sampel Jatim 2 & 0.011 & 0.000 & & & & & & & & & & & & & & \\
\hline 3 & Sampel Jatim 3 & 0.011 & 0.000 & 0.000 & & & & & & & & & & & & & \\
\hline 4 & Sampel Jatim 4 & 0.017 & 0.009 & 0.009 & 0.009 & & & & & & & & & & & & \\
\hline 5 & SampelJatim 5 & 0.017 & 0.009 & 0.009 & 0.009 & 0.000 & & & & & & & & & & & \\
\hline 6 & Sampel Jabar 2 & 0.011 & 0.000 & 0.000 & 0.000 & 0.009 & 0.009 & & & & & & & & & & \\
\hline 7 & Sampel Jabar 4 & 0.011 & 0.000 & 0.000 & 0.000 & 0.009 & 0.009 & 0.000 & & & & & & & & & \\
\hline 8 & Sampel Jabar 6 & 0.012 & 0.001 & 0.001 & 0.001 & 0.010 & 0.010 & 0.001 & 0.001 & & & & & & & & \\
\hline 9 & Sampel Jabar 9 & 0.011 & 0.000 & 0.000 & 0.000 & 0.009 & 0.009 & 0.000 & 0.000 & 0.001 & & & & & & & \\
\hline 10 & Sampel Jabar 10 & 0.011 & 0.000 & 0.000 & 0.000 & 0.009 & 0.009 & 0.000 & 0.000 & 0.001 & 0.000 & & & & & & \\
\hline 11 & Sampel Jateng 2 & 0.015 & 0.010 & 0.010 & 0.010 & 0.004 & 0.004 & 0.010 & 0.010 & 0.011 & 0.010 & 0.010 & & & & & \\
\hline 12 & Sampel Jateng 3 & 0.015 & 0.010 & 0.010 & 0.010 & 0.004 & 0.004 & 0.010 & 0.010 & 0.011 & 0.010 & 0.010 & 0.000 & & & & \\
\hline 13 & Sampel Jateng 5 & 0.015 & 0.010 & 0.010 & 0.010 & 0.004 & 0.004 & 0.010 & 0.010 & 0.011 & 0.010 & 0.010 & 0.000 & 0.000 & & & \\
\hline 14 & Sampel Jateng 8 & 0.015 & 0.010 & 0.010 & 0.010 & 0.004 & 0.004 & 0.010 & 0.010 & 0.011 & 0.010 & 0.010 & 0.000 & 0.000 & 0.000 & & \\
\hline 15 & Sampel Jateng 9 & 0.016 & 0.011 & 0.011 & 0.011 & 0.002 & 0.002 & 0.011 & 0.011 & 0.012 & 0.011 & 0.011 & 0.001 & 0.001 & 0.001 & 0.001 & \\
\hline 16 & M. reticulatus & 0.000 & 0.011 & 0.011 & 0.011 & 0.017 & 0.017 & 0.011 & 0.011 & 0.012 & 0.011 & 0.011 & 0.015 & 0.015 & 0.015 & 0.015 & 0.016 \\
\hline
\end{tabular}

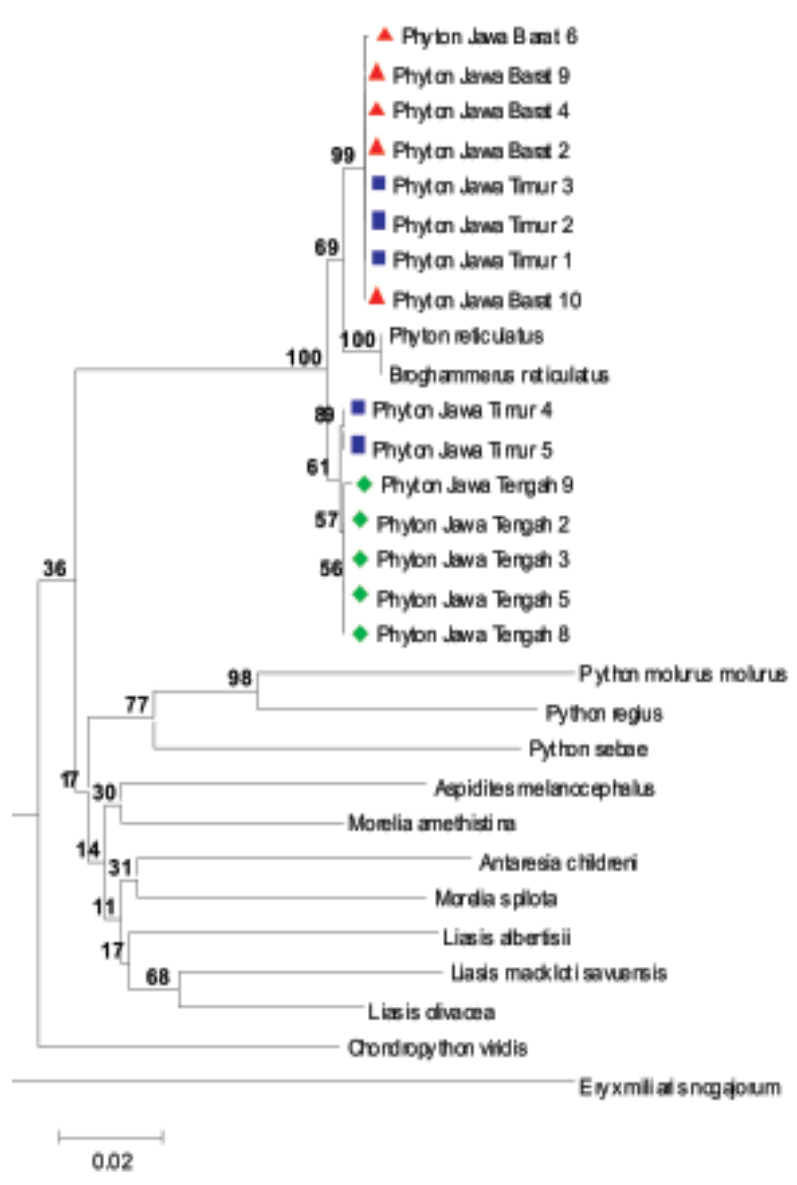

A

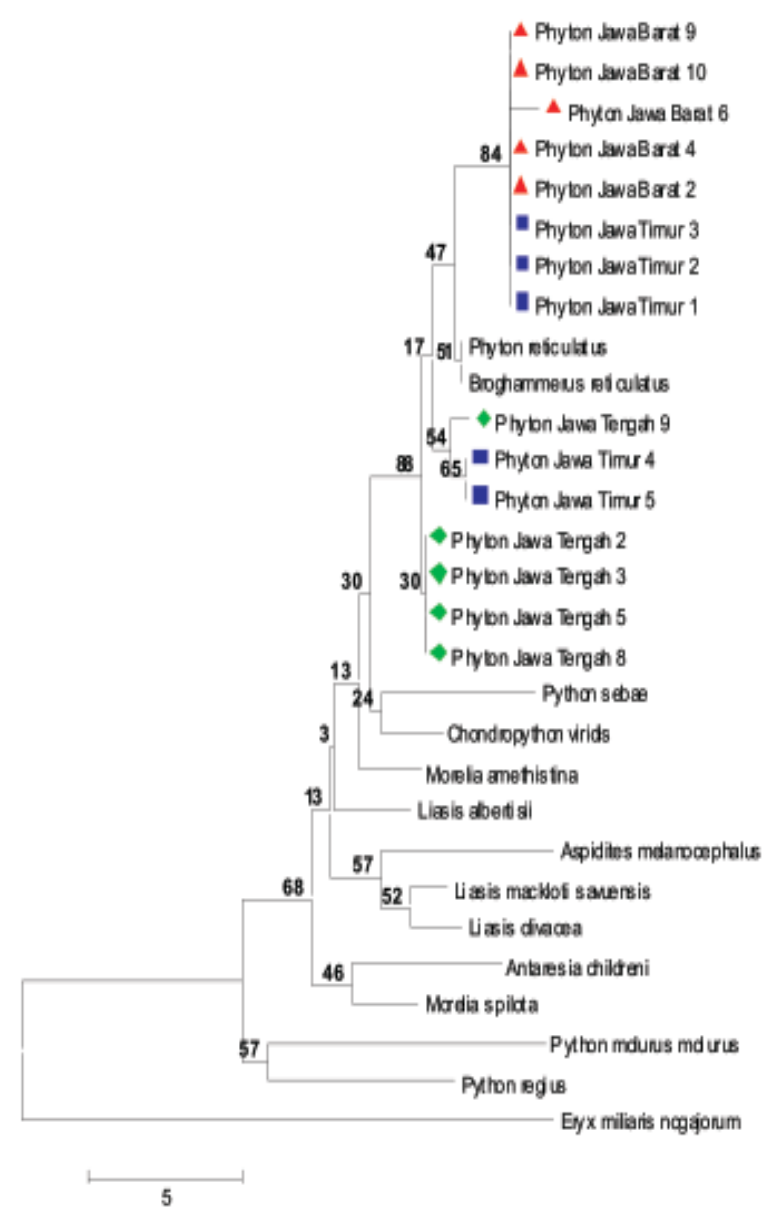

B

Gambar 2. Filogram Malayopython reticulatus asal Jawa Barat, Jawa Tengah dan Jawa Timur berdasar sekuen nukleotida (819 nukleotida) (A) dan sekuen asam amino (273 aa) (B) gen Sitokrom B menggunakan metode Neighbor joining dengan nilai bootstrap 1000 kali 
Filogram $M$. reticulatus sampel penelitian lokalitas Jawa Barat, Jawa Tengah dan Jawa Timur berdasar sekuen nukleotida (819 nukleotida) (Gambar 2A) dan berdasar sekuen asam amino (273 aa) (Gambar 2B) gen sitokrom b parsial menggunakan metode Neighbor joining, dengan nilai bootstrap 1000 kali menunjukkan hasil bahwa $M$. reticulatus lokal Jawa Tengah merupakan kelompok yang berbeda dari $M$. reticulatus lokal Jawa Barat, sedangkan $M$. reticulatus lokalJawa Timur ada yang mirip lokalitas Jawa Tengah dan ada yang mirip lokalitas Jawa Barat.

Pada Gambar 2A dan 2B terlihat filogram $M$. reticulatus asal Jawa Barat, Jawa Tengah dan Jawa Timur berada dalam percabangan yang sama dengan Python/Broghammerus/ Malyopython reticulatus GenBank. Hal ini menunjukkan bahwa $M$. reticulatus asal Jawa Barat, Jawa Tengah dan Jawa Timur adalah sesuai dengan $M_{\text {. }}$ reticulatus GenBank. Hasil ini sesuai dengan jarak genetik yang kecil yaitu 1,1-1,7\%. Kelompok M. reticulatus asal Jawa Barat dan beberapa dari Jawa Timur berada dalam cabang yang sama dengan $M$. reticulatus GenBank, sedangkan $M$. reticulatus asal Jawa Tengah dan beberapa dari Jawa Timur berada dalam cabang berbeda. Pemisahan ini didukung dengan nilai bootstrap 100\% (Gambar 2A) dan 88\% (Gambar 2B).

Berdasar kedua gambar (2A dan 2B) terlihat jelas bahwa $M$. reticulatus asal Jawa Barat dan Jawa Tengah berbeda sedangkan sampel dari Jawa Timur hasilnya tidak konsisten. Hal ini mungkin terjadi akibat sampel yang tidak valid asal-usul lokalitasnya, karena perbedaan nukleotida yang sangat kecil sehingga hasilnya kurang akurat ataupun sampel ternyata adalah ular dari lokalitas propinsi selain Jawa Timur yang lepas ke alam liar.

\section{SIMPULAN}

Berdasar hasil sekuensing gen sitokrom b parsial dapat disimpulkan bahwa $M$. reticulatus Jawa memiliki keseragaman panjang nukleotida 819 bp. Filogenetik M. reticulatus asal Jawa Barat dan beberapa asal Jawa Timur berada dalam cabang yang sama dengan $M$. reticulatus GenBank, sedangkan $M$. reticulatus asal Jawa Tengah dan beberapa dari Jawa Timur berada dalam cabang berbeda.

\section{SARAN}

Perlu penelitian lebih lanjut dengan jumlah sampel yang lebih banyak dan validitas lokalitas sehingga hasil lebih akurat.

\section{UCAPAN TERIMAKASIH}

Terimakasih disampaikan kepada Fakultas Kedokteran Hewan UGM atas kesempatan dan dana penelitian melalui Program Hibah Multidisipin FKH UGM tahun 2013.

\section{DAFTAR PUSTAKA}

Auliya MA. 2003. Taxonomy, Life History and Conservation of Giant Reptiles in West Kalimantan.Ph.D.Thesis. Bonn. University of Bonn.

Auliya, MA, Mausfeld, P, Schmitz, A, Bohme, W. 2002. Review of the reticulated python (Python reticulatus Schneider, 1801) with the description of new subspecies from Indonesia. The Science of Natur 89: 201213.

Barker DG, Barker TM, Davis MA, Schuett GW. 2015. A review of the systematics and taxonomy of Pythonidae: an ancient serpent lineage. Zoological Journal of the Linnean Society 175: 1-19.

Butorina OT, Seibold I, Helbig A. 2000. Evolution of the Mitochondrial DNA Cytochrome B Gene in Tetraonidae Birds. Genetics 36: 925-931.

Kaiser H, Crother BI, Kelly CMR, Luiselli L, O'Shea M, Ota H, Passos P, Schleip WD, Wüster W. 2013. Best Practices: In the 21st Century, Taxonomic Decisions in Herpetology are Acceptable Only When Supported by a Body of Evidence and Published via Peer-Review. Herpetological Review 44(1): 8-23.

Low MR, David PB, Marcus T, Neves LC. 2016. Malayopython reticulatus (Reticulated Python) Diet. Herpetological Review 47(1): 148-149.

Ozawa T, Hayashi S, Mikhelson MV. 1997. Phylogenetic position of Mammoth and Steller's sea cow within Tethitheria demonstrated by mitochondrial DNA sequences. J Mol Evol 44: 406-413 
Raharjo S. 2008. Medis Veteriner dan Herpetofauna Indonesia. Makalah Seminar Nasional dan Kongress I Perhimpunan Herpetologi Indonesia 2008; Mengungkap Dunia Herpetologi Indonesia 2008, Fakultas Biologi UGM 24-25 Mei 2008.

Randi E, Lucchini V. 1998. Organization and Evolution of Mitochondrial DNA Control Region in the Avian Genus Alectoris. J Mol Evol 47: 449-462.

Rawlings LH, Rabosky DL, Donnellan SC, Hutchinson MN. 2008. Python phylogenetics: inference from morphology and mitochondrial DNA. Biological Journal of the Linnean Society 93(3): 603-619.

Relox RE, Emmanuel PL, Fritzie BAC. 2011. Herpetofaunal Endemism and Diversity in Tropical Forests of Mt. Hamiguitan in the Philippines. Herp Cons Biol 6(1): 107"113.

Reynolds RG, Niemiller ML, Revell LJ. 2014. Toward a tree-of-life for the boas and pythons: multilocus species-level phylogeny with unprecedented taxon sampling. Molecular Phylogenetics and Evolution 71: 201-213.

Reyes A, Gissi, C, Pesole G, Saccone C. 1998. Asymmetrical Directional Mutation Pressure in the Mitochondrial Genome of Mammals. J Mol Biol Evol 15: 957-966.

Sambrook J, Fritsch EF, Maniatis T. 1989. Molecular Cloning: A Laboratory Manual. $2^{\text {nd }}$ edition. New York: Cold Spring Harbor Laboratory Press.

Wanger TC,Motzke I, Saleh S, Iskandar DT. 2011. The amphibians and reptiles of the Lore Lindu National Park area, Central Sulawesi, Indonesia. Salamandra 47(1): 17 29

Widayanti R, Solihin DD, Sajuthi D, Perwitasari D. 2006, Kajian Penanda Genetik Gen Cytochrome B pada Tarsius sp. J Sain Veteriner 24(1): 1-8. 